\title{
Low vertical transfer rates of carbon inferred from radiocarbon analysis in an Amazon Podzol
}

\author{
C. A. Sierra ${ }^{1}$, E. M. Jiménez ${ }^{1,2}$, B. Reu ${ }^{3}$, M. C. Peñuela ${ }^{2}$, A. Thuille ${ }^{1}$, and C. A. Quesada ${ }^{4}$ \\ ${ }^{1}$ Max Planck Institute for Biogeochemistry, Hans-Knöll-Str. 10, 07745 Jena, Germany \\ ${ }^{2}$ Research Group on Ecology of Tropical Terrestrial Ecosystems, National University of Colombia Sede Amazonia, Leticia, \\ Colombia \\ ${ }^{3}$ Institute of Biology, University of Leipzig, 04103 Leipzig, Germany \\ ${ }^{4}$ Instituto Nacional de Pesquisas da Amazônia, Manaus, Brazil
}

Correspondence to: C. A. Sierra (csierra@bgc-jena.mpg.de)

Received: 13 January 2013 - Published in Biogeosciences Discuss.: 22 February 2013

Revised: 6 May 2013 - Accepted: 7 May 2013 - Published: 1 June 2013

\begin{abstract}
Hydromorphic Podzol soils in the Amazon Basin generally support low-stature forests with some of the lowest amounts of aboveground net primary production (NPP) in the region. However, they can also exhibit large values of belowground NPP that can contribute significantly to the total annual inputs of organic matter into the soil. These hydromorphic Podzol soils also exhibit a horizon rich in organic matter at around 1-2 $\mathrm{m}$ depth, presumably as a result of eluviation of dissolved organic matter and sesquioxides of $\mathrm{Fe}$ and Al. Therefore, it is likely that these ecosystems store large quantities of carbon by (1) large amounts of $\mathrm{C}$ inputs to soils dominated by their high levels of fine-root production, (2) stabilization of organic matter in an illuviation horizon due to significant vertical transfers of $\mathrm{C}$. To assess these ideas we studied soil carbon dynamics using radiocarbon in two adjacent Amazon forests growing on contrasting soils: a hydromorphic Podzol and a well-drained Alisol supporting a high-stature terra firme forest. Our measurements showed similar concentrations of $\mathrm{C}$ and radiocarbon in the litter layer and the first $5 \mathrm{~cm}$ of the mineral soil for both sites. This result is consistent with the idea that the hydromorphic Podzol soil has similar soil $\mathrm{C}$ storage and cycling rates compared to the well-drained Alisol that supports a more opulent vegetation. However, we found important differences in carbon dynamics and transfers along the vertical profile. At both soils, we found similar radiocarbon concentrations in the subsoil, but the carbon released after incubating soil samples presented radiocarbon concentrations of recent origin in the Alisol, but not in the Podzol. There were no indications of incorpora-
\end{abstract}

tion of C fixed after 1950 in the illuvial horizon of the Podzol. With the aid of a simulation model, we predicted that only a minor fraction $(1.7 \%)$ of the labile carbon decomposed in the topsoil is transferred to the subsoil of the Podzol, while this proportional transfer is about $30 \%$ in the Alisol. Furthermore, our estimates were 8 times lower than previous estimations of vertical C transfers in Amazon Podzols, and question the validity of these previous estimations for all Podzols within the Amazon Basin. Our results also challenge our previous ideas about the genesis of these particular soils and suggest that either they are not true Podzols or the podzolization processes had already stopped.

\section{Introduction}

It is well known that differences in soils have profound effects on the aboveground net primary production (NPP) of tropical forests (Cleveland et al., 2011; Quesada et al., 2012). Less clear, however, is the role of soils controlling total NPP and total carbon storage in the tropics. Almost all soil orders are represented within the tropical biome, spanning along a wide range of soil morphology and genesis (Townsend et al., 2008; Quesada et al., 2010, 2011). These different soils represent a large heterogeneity in belowground characteristics, from nutrient-depleted to nutrient-rich soils, and from hydromorphic to well-drained. These soils, in interaction with other variables such as climate, can control the patterns of carbon allocation between below- and aboveground plant 
parts (Aragao et al., 2009; Malhi et al., 2011) as well as the speed of organic matter decomposition (Wieder et al., 2009; Cleveland et al., 2011), which together determine the capacity of forest ecosystems to store carbon (Chapin et al., 2006).

Particularly interesting in terms of their carbon dynamics and their carbon storage potential are the poorly drained Podzol soils of the Amazon Basin. These soils cover approximately $1.5 \times 10^{5} \mathrm{~km}^{2}$, and can potentially store $13.6 \pm$ $1.1 \mathrm{PgC}$ in their illuviation (Bh) horizon (Montes et al., 2011; Lucas et al., 2012). This horizon contains large amounts of organic matter associated with sesquioxides, most likely eluviated from upper horizons (Klinge, 1965; Bravard and Righi, 1989; Horbe et al., 2004; Buurman and Jongmans, 2005; Montes et al., 2011; Lucas et al., 2012); however, the genesis and classification of these soils are still debated (Bravard and Righi, 1989; do Nascimento et al., 2004; Buurman and Jongmans, 2005). These Podzols are common in central Amazonia north of Manaus and in the Guyana Shield as well as in isolated areas in Colombia and Peru (Quesada et al., 2011). They exhibit a particular vegetation type, consisting mainly of small-stature trees growing at high densities (Klinge, 1965).

In some cases, forests growing on these hydromorphic Podzols may exhibit low values of aboveground biomass and aboveground NPP, but large values of fine-root biomass and belowground productivity (Duivenvoorden and Lips, 1995; Aragao et al., 2009; Jiménez et al., 2009). For example, data from the Colombian Amazon show that aboveground NPP is $53 \%$ higher in a high-stature forest growing on an Plinthosol soil than in a low-stature forest growing on a hydromorphic Podzol. However, belowground NPP is $36 \%$ higher in the Podzol soil than in the Plinthosol soil, which suggests a compensation between carbon investments above and below ground. Differences in total NPP are only $16 \%$ between these two sites, an indication that soils exert a strong control on ecosystem carbon allocation and the carbon balance of these systems.

In addition, vertical transfers of dissolved organic carbon (DOC) in hydromorphic podzols can be significant. Montes et al. (2011) estimated transfers of DOC from the A to the E horizon as $55.5 \mathrm{~g} \mathrm{~m}^{-2} \mathrm{yr}^{-1}$, and from the $\mathrm{E}$ horizon to the Bh horizon as $16.8 \mathrm{~g} \mathrm{~m}^{-2} \mathrm{yr}^{-1}$ in Podzols near São Gabriel da Cachoeira city, Brazil.

Together, these results from Colombia and Brazil suggest that it is possible that forests growing under hydromorphic Podzols not only show levels of total NPP as high as those observed under high-stature terra firme forests growing under more favorable conditions, but also have the potential to store large quantities of organic matter in an illuviation (Ortsteinic) horizon where the carbon is tightly associated with sesquioxides of $\mathrm{Fe}$ and $\mathrm{Al}$. In other words, high levels of belowground NPP in the topsoil (A horizon) can contribute significant amounts of carbon that can be stabilized by mineral interactions in the subsoil.
In this study, we used radiocarbon measurements to get insights into the soil carbon balance of two forests growing under contrasting soils: one under an Alisol supporting a tall-stature terra firme forest, and the other under a hydromorphic Podzol supporting a low-stature, highly dense forest. Radiocarbon is a useful tracer to study soil organic matter dynamics; in particular, radiocarbon produced during nuclear bomb tests in the late 1940s and early 1950s helps to determine the speed of carbon accumulation and turnover in soils (Trumbore, 2009). Furthermore, measurements of radiocarbon respired from incubated soils can give additional insights about the different fractions comprising soil organic matter (Gaudinski et al., 2000; Sierra et al., 2012b).

To assess the carbon storage potential of the forest growing under the hydromorphic Podzol, we were interested in testing two hypotheses:

- Hypothesis 1: Higher fine-root production in the hydromorphic Podzol relative to that in the Alisol results in similar amounts of total carbon inputs to both soils and therefore similar amounts of carbon storage in the topsoil. $\triangle{ }^{14} \mathrm{C}$ values in both soils should not differ, indicating similar rates of soil $\mathrm{C}$ cycling in the topsoil. Evidence against this hypothesis would imply differences in the rates of decomposition between the two forests.

- Hypothesis 2: Significant rates of C transfer along the vertical profile in the hydromorphic Podzol result in accumulation of radiocarbon with the $\Delta^{14} \mathrm{C}$ signature of the bomb spike. Failure to detect post-bomb $\Delta^{14} \mathrm{C}$ values and rejection of this hypothesis would imply that accumulation of organic matter in the Ortsteinic horizon is not necessarily related to eluviation from upper horizons.

\section{Methods}

\subsection{Study sites and sample collection}

The study site is located in the Colombian Amazon, $24.7 \mathrm{~km}$ north of the city of Leticia (Table 1). In February 2011, we collected samples of the organic layer and the mineral horizon at different soil depths of an Ortsteinic Podzol and a Haplic Alisol, both located on permanent forest plots at El Zafire Biological Station, ZAR-01 and ZAR-04 respectively. Additional details about the permanent plots are provided in Aragao et al. (2009), Jiménez et al. (2009), and Quesada et al. (2010). Mean annual temperature for the region fluctuates in a small range around $25^{\circ} \mathrm{C}$; mean annual precipitation was measured as $3335 \mathrm{~mm}$ between the years 1973 and 2006 at the Vásquez Cobo airport in Leticia.

The Haplic Alisol (ZAR-04) is located on a gentle slope of a landscape characterized by an undulating topography. The site we sampled is well drained and supports a tall-stature terra firme forest. Clay fraction mineralogy is dominated 
Table 1. Basic description of the two sites and their productivity. Productivity estimates from Jiménez et al. (2013).

\begin{tabular}{llll}
\hline Property & Low-stature forest & High-stature forest & Units \\
\hline WRB classification & Ortsteinic Podzol & Haplic Alisol & - \\
Plot name & ZAR-01 & ZAR-04 & - \\
Coordinates & $4.007^{\circ} \mathrm{S}, 69.901^{\circ} \mathrm{W}$ & $4.007^{\circ} \mathrm{S}, 69.906^{\circ} \mathrm{W}$ & - \\
Altitude & 127 & 130 & $\mathrm{~m} \mathrm{a.s.1.}$ \\
Fine-root production & 2.98 & 1.53 & $\mathrm{Mg} \mathrm{Cha}^{-1} \mathrm{yr}^{-1}$ \\
Litterfall & 2.48 & 4.72 & $\mathrm{Mg} \mathrm{Cha}^{-1} \mathrm{yr}^{-1}$ \\
\hline
\end{tabular}

by kaolinite (39\%), mica (23\%) and smectite (25\%), with traces of quartz and gibbsite accounting for the remainder. The soil consists of a litter layer of approximately $2.5 \mathrm{~cm}$, followed by an A horizon from 0 to $20 \mathrm{~cm}$ depth. This A horizon is characterized by an ochric epipedon, brownish yellow color, large number of roots (mostly fine and medium size), and low bulk density (Table 2). Soil structure is in blocks and well aggregated with a sandy loam texture, with sandy clay loam at the lower part of the horizon (increase in clay content with depth). The B horizon can be found between 20 and $90 \mathrm{~cm}$ depth. It has a sandy clay loam texture, contains few roots and is yellow to pale yellow in color. Soil structure is in blocks, but degree of aggregation is lower than upper horizons. Bulk density increases sharply in this horizon $\left(1.3-1.6 \mathrm{~g} \mathrm{~cm}^{-3}\right)$.

The Ortsteinic Podzol (ZAR-01) supports a low-stature highly dense forest, locally known as varillal, which consists of small-diameter trees growing at an average density of about 900 stems ha $^{-1}$ (>10 cm diameter). This Podzol soil is covered by a thick root mat in the A horizon, which is characterized by a loamy sand texture, and a single grain, with loose structure. Bulk density is high $\left(1.4-1.8 \mathrm{~g} \mathrm{~cm}^{-3}\right)$ in this A horizon. The underlying $\mathrm{E}$ horizon consists mostly of bleached white sand and very low $\mathrm{C}$ and nutrient contents. Its texture is sandy loam or loamy sand, with single grain and loose or no structure. Bulk density values are high $\left(1.9 \mathrm{~g} \mathrm{~cm}^{-3}\right)$, and almost no roots can be seen in this horizon. Below the E-horizon there is a cemented Bh horizon with high contents of $\mathrm{Al}$ and higher contents of clay than the sandy horizons above it. This horizon constrains drainage and has gleyic properties (reduced and grayish). The soil is located on a flat topography, and it is seasonally flooded (water level $5-10 \mathrm{~cm}$ above ground). We do not have continuous records of the depth of the water table and its seasonality; however, our personal observations suggest that the impermeable Bh horizon impedes the vertical movement of water and keeps the E horizon continuously waterlogged. Mineralogy is predominantly quartz across the profile. This soil is often characterized as one of the nutrient-poorest soils in Amazonia (Table 2, Quesada et al., 2010). Both forests can be considered primary in the sense that we are not aware of any indication of previous anthropogenic disturbance as well as for their current protection status as a forest reserve.
To test hypothesis 1 we sampled the litter layer and the mineral horizon using a percussion soil corer of $5 \mathrm{~cm}$ diameter and $5 \mathrm{~cm}$ depth. Five random points were located inside the permanent plots to sample the topsoil.

To test hypothesis 2 we collected a different set of samples. We sampled the subsoil in profiles dug outside the permanent plots to avoid disturbances to the ongoing vegetation monitoring. We sampled one profile per forest type. At ZAR-01, we sampled the same soil profile described in Quesada et al. (2011), and at ZAR-04 we sampled a new profile. In these profiles we used the same soil corer sampling at depths 10 , 50 , and $70 \mathrm{~cm}$, which correspond to the $\mathrm{A}, \mathrm{E}$, and $\mathrm{Bh}$ horizons in ZAR-01. At ZAR-04 we sampled at depths 5, 15, and $55 \mathrm{~cm}$, which correspond to the $\mathrm{A}$, and $\mathrm{B}$ horizons of the Alisol.

All samples were stored in plastic bags, air-dried, and preprocessed at the laboratory of Natural Products and Seeds of the National University of Colombia at Leticia. Samples were passed through a $2 \mathrm{~mm}$ sieve excluding all stones and big roots ( $>2 \mathrm{~mm}$ in diameter).

Additionally, we report here detailed profile characteristics for the two plots from two profiles sampled earlier in 2006 (Table 2, Quesada et al., 2010, 2011). These data are presented here as reference, only for the purpose of describing the general characteristics of the soil and interpreting our results.

\subsection{Laboratory and statistical analyses}

Soil samples were analyzed for carbon and nitrogen content by dry combustion with a $\mathrm{CN}$ analyzer (Elementar Vario Max) at the Max Planck Institute for Biogeochemistry in Jena, Germany. Additionally, the radiocarbon signature of bulk soil carbon and respired $\mathrm{CO}_{2}$ derived from soil incubations were analyzed by accelerator mass spectrometry (AMS). Differentiating between radiocarbon signatures of bulk soil carbon and respired $\mathrm{CO}_{2}$ allows for differentiating the source of more stable carbon associated with minerals and more readily available carbon for microbial consumption. We incubated the soil in closed glass jars at $25^{\circ} \mathrm{C}$ until heterotrophic organisms released a sufficient amount of $\mathrm{C}$ for graphitization and radiocarbon measurements, $1.8-2.0 \mathrm{mg}$ of carbon corresponding to a $\mathrm{CO}_{2}$ concentration of $2 \%$ in the glass jars. The $\mathrm{CO}_{2}$ concentration in the jars was monitored 
using an infrared gas analyzer (Li-6262). Incubation time varied among samples depending on their $\mathrm{C}$ concentrations, from a few days to up to a month. After incubation, the air inside the jar was transferred into injection bottles, which were connected to a vacuum extraction line separating the $\mathrm{CO}_{2}$ from water vapor and other gases, and transferring it into reaction tubes containing $\mathrm{Zn}$ and $\mathrm{TiH}_{2}$ (Gaudinski et al., 2000). The reaction tubes were heated to $550^{\circ} \mathrm{C}$, reducing the $\mathrm{CO}_{2}$ to graphite and precipitating it on iron powder. The graphiteiron mixture was pressed and subsequently analyzed for its radiocarbon signature by AMS. Radiocarbon measurements were carried out at the WM Keck Carbon Cycle AMS facility at the University of California at Irvine, USA.

To test for statistical differences in the carbon and radiocarbon content of the topsoil samples (hypothesis 1), we fitted a linear model of the form $y_{i}=\beta_{0}+\beta_{1}$ Plot $+\beta_{2}$ Horizon + $\beta_{3}$ Plot $\cdot$ Horizon $+\epsilon_{i}$, where $y_{i}$ is a carbon or radiocarbon value in a sample, and $\epsilon_{i}$ is the error term associated with each sample. Significant values of the $\beta$ coefficients, assessed by an analysis of variance $F$ test at a significant level $\alpha=0.05$, imply differences in carbon or radiocarbon values between plots, horizon, or horizons between plots. For comparisons among specific horizons, we used the post hoc Tukey honestly significant difference (HSD) test.

\subsection{Radiocarbon model}

To interpret the results obtained from the radiocarbon samples in the depth profiles (hypothesis 2), we used a compartment model with two pools of different decomposition rates (fast and slow), and with coefficients that account for transfers of carbon along the depth profile. The approach is similar to other models previously developed to interpret radiocarbon data (e.g., Trumbore et al., 1995; Gaudinski et al., 2000; Baisden and Parfitt, 2007; Sierra et al., 2012b).

In the model we assume two horizons, the topsoil and the subsoil, and at each horizon carbon is distributed between two pools of different decomposition rates. In the topsoil, carbon inputs are from litterfall and fine-root production, while in the subsoil carbon inputs to the pools are from fine-root production and vertical $\mathrm{C}$ transfers from the topsoil (Fig. 1).

The model is mathematically defined by a set of differential equations

$$
\begin{aligned}
\frac{\mathrm{d} C_{\mathrm{ft}}}{\mathrm{d} t} & =\gamma_{1}\left(L+R_{\mathrm{t}}\right)-k_{1} C_{\mathrm{ft}} \\
\frac{\mathrm{d} C_{\mathrm{st}}}{\mathrm{d} t} & =\left(1-\gamma_{1}\right)\left(L+R_{\mathrm{t}}\right)-k_{2} C_{\mathrm{st}} \\
\frac{\mathrm{d} C_{\mathrm{fs}}}{\mathrm{d} t} & =\gamma_{2} R_{\mathrm{s}}+\alpha_{3,1} k_{1} C_{\mathrm{ft}}-k_{3} C_{\mathrm{fs}} \\
\frac{\mathrm{d} C_{\mathrm{ss}}}{\mathrm{d} t} & =\left(1-\gamma_{2}\right) R_{\mathrm{s}}+\alpha_{4,2} k_{2} C_{\mathrm{st}}-k_{4} C_{\mathrm{ss}},
\end{aligned}
$$

where $L$ represents the amount of litter inputs to the soil from aboveground litterfall; $R_{\mathrm{t}}$ and $R_{\mathrm{S}}$ the amount of root inputs

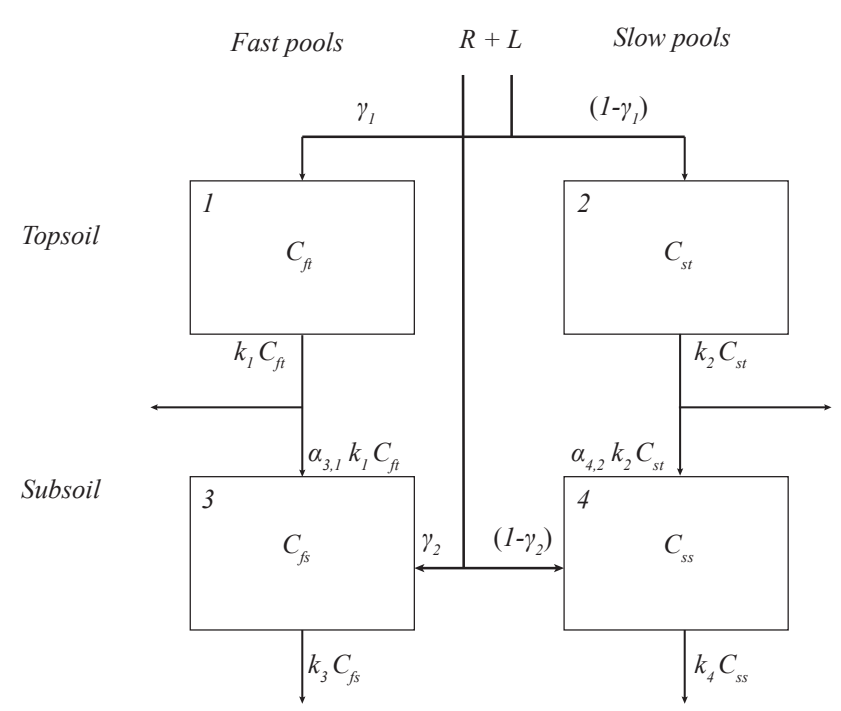

Fig. 1. Graphical representation of the model structure for carbon cycling in the studied sites. This model structure represents the system of equations in Eq. (1).

to the topsoil and the subsoil, respectively; $C_{\mathrm{ft}}$ the amount of carbon stored in the fast pool in the topsoil; $C_{\text {st }}$ the amount of carbon in the slow pool in the topsoil; $C_{\mathrm{fs}}$ the amount of carbon in the fast pool in the subsoil; and $C_{\mathrm{ss}}$ the amount of carbon in the slow pool in the subsoil. $\gamma_{1}$ and $\gamma_{2}$ are partitioning coefficients that indicate the proportion of carbon inputs that go to the fast cycling pool in the topsoil and subsoil, respectively. The transfer coefficients $\alpha_{3,1}$ and $\alpha_{4,2}$ represent the proportion of decomposed carbon from the fast and slow cycling pools in the topsoil that move downward to the subsoil, respectively. The subscript of these transfer coefficients follows the conventions described in Sierra et al. (2012a) for this type of models, in which 3,1 represents transfers from pool 1 to 3; and 4,2 transfers from pool 2 to 4 . To test for differences between the two forests in the amount of carbon transferred from the topsoil to the subsoil, we will focus on finding differences in the $\alpha_{j, i}$ coefficients.

Notice that in this model the total amount of $\mathrm{C}$ that leaves from pool $i$ is calculated as $k_{i} C_{i}$, and only a proportion $\alpha_{j, i}$ is transferred vertically to the other pools. The remaining proportion of carbon $\left(1-\alpha_{j, i}\right)$ includes other losses such as respiration and lateral transfers, but we do not explicitly separate these losses in the model.

Litter inputs to the subsoil were obtained from measurements of litterfall and fine root production up to $20 \mathrm{~cm}$ taken at the two plots (Jiménez et al., 2009; Jiménez et al., 2013). Root inputs to the subsoil $R_{\mathrm{S}}$ in the Podzol were not considered because roots are not present below the A horizon in this soil. For the Alisol, root inputs were calculated using our estimates up to $20 \mathrm{~cm}$ and using a model of depth distribution proposed by Jackson et al. (1996). We calculated the cumulative amount of root inputs up to $55 \mathrm{~cm}$ and subtracted the 
Table 2. Soil profile characterization for pits dug in a small-stature forest growing under a Podzol (ZAR-01), and a tall-stature forest growing under an Alisol soil (ZAR-04). ECEC represents effective cation exchange capacity. Details about sampling and laboratory analyses are provided in Quesada et al. (2010).

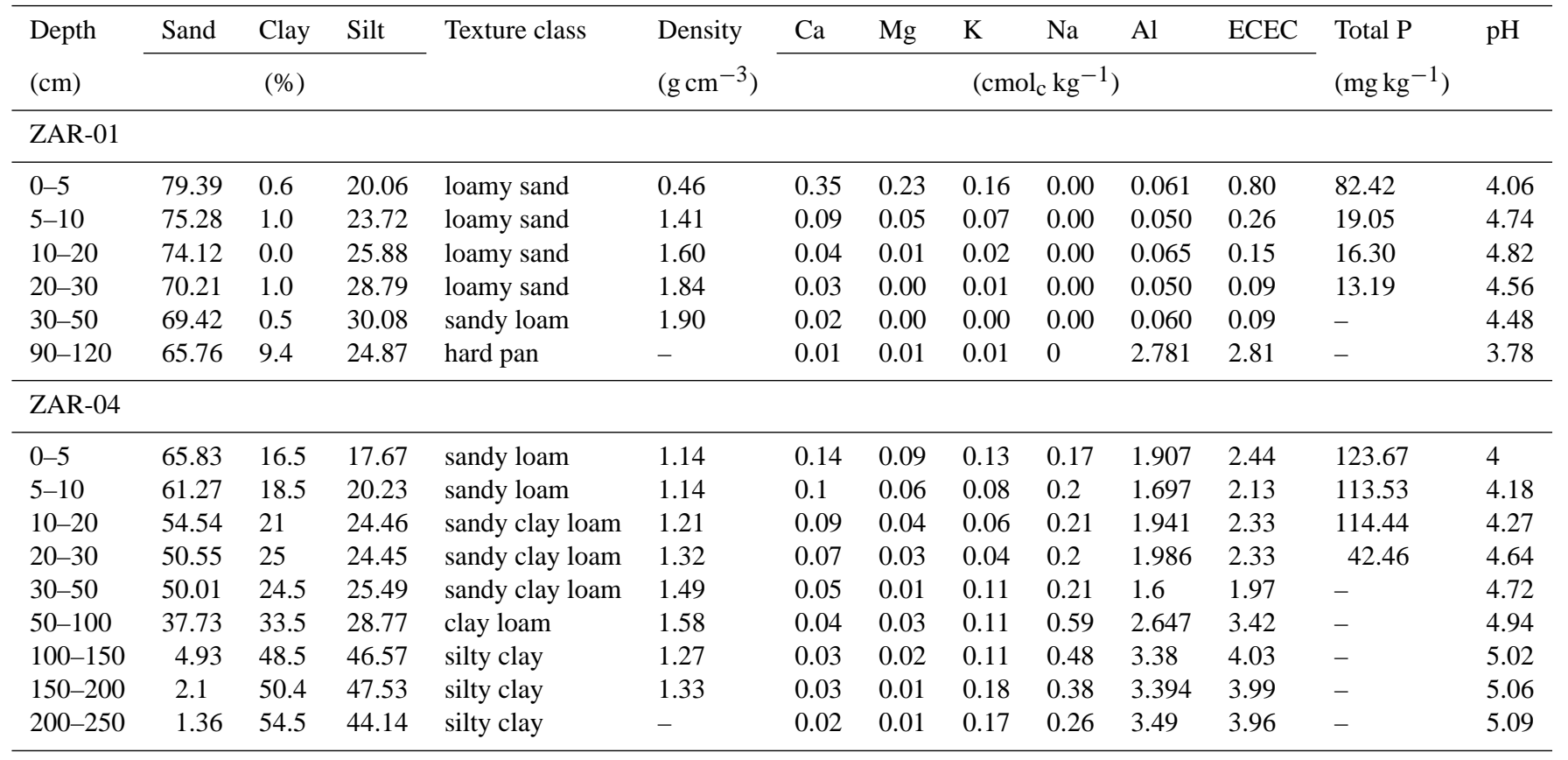

cumulative amount up to $20 \mathrm{~cm}$ to obtain the amount of root inputs to the subsoil.

The radiocarbon version of this model is identical to the carbon model above, except that it includes radioactive decay of the ${ }^{14} \mathrm{C}$. The system of equations is given by

$$
\begin{aligned}
& \frac{\mathrm{d} F_{\mathrm{ft}} C_{\mathrm{ft}}}{\mathrm{d} t}=\gamma_{1} F_{\mathrm{a}}\left(L+R_{\mathrm{t}}\right)-k_{1} F_{\mathrm{ft}} C_{\mathrm{ft}}-\lambda F_{\mathrm{ft}} C_{\mathrm{ft}} \\
& \frac{\mathrm{d} F_{\mathrm{st}} C_{\mathrm{st}}}{\mathrm{d} t}=\left(1-\gamma_{1}\right) F_{\mathrm{a}}\left(L+R_{\mathrm{t}}\right)-k_{2} F_{\mathrm{st}} C_{\mathrm{st}}-\lambda F_{\mathrm{st}} C_{\mathrm{st}} \\
& \frac{\mathrm{d} F_{\mathrm{fs}} C_{\mathrm{fs}}}{\mathrm{d} t}=\gamma_{2} R_{\mathrm{s}}+\alpha_{3,1} k_{1} F_{\mathrm{ft}} C_{\mathrm{ft}}-k_{3} F_{\mathrm{fs}} C_{\mathrm{fs}}-\lambda F_{\mathrm{fs}} C_{\mathrm{fs}} \\
& \frac{\mathrm{d} F_{\mathrm{ss}} C_{\mathrm{ss}}}{\mathrm{d} t}=\left(1-\gamma_{2}\right) R_{\mathrm{s}}+\alpha_{4,2} k_{2} F_{\mathrm{st}} C_{\mathrm{st}}-k_{4} F_{\mathrm{ss}} C_{\mathrm{ss}}-\lambda F_{\mathrm{ss}} C_{\mathrm{ss}},
\end{aligned}
$$

where $\lambda$ is the radioactive decay constant, $F_{\mathrm{a}}$ the fraction of radiocarbon in atmospheric $\mathrm{CO}_{2}$, and $F_{i}$ is the radiocarbon fraction for each pool $i$ expressed as absolute fraction modern, i.e., the absolute ratio of sample to standard, corrected for radiodecay in the year of measurement $y$ (cf. Stuiver and Polach, 1977):

$$
F=\frac{\left.{ }^{\frac{14}{12} \mathrm{C}}\right|_{\text {sample },-25}}{\left.0.95 \frac{14 \mathrm{C}}{{ }^{12} \mathrm{C}}\right|_{\mathrm{OX},-19} e^{(y-1950) / 8267}} .
$$

We implemented this model in the R environment for computing using the SoilR package (Sierra et al., 2012a). Atmospheric radiocarbon data were obtained from the IntCal09 dataset (Reimer et al., 2009) for the pre-bomb period, and the dataset from Levin and Kromer (2004) afterwards.

Radiocarbon measurements from bulk soils and $\mathrm{CO}_{2}$ evolved from incubations in the sampled profiles were used to find parameters for the radiocarbon model. We only used the radiocarbon values and the carbon content of the soil to parameterize the model, and omitted the values of soil respiration obtained during the incubations. The idea is that the radiocarbon value of the respired $\mathrm{CO}_{2}$ only provides information on the source of $\mathrm{C}$ being decomposed and not necessarily on the total amount of $\mathrm{C}$ decomposed by microorganisms, which can also be transformed into other compounds.

All code and data to reproduce all results presented here are provided in the Supplement.

\section{Results}

\subsection{Topsoil}

We found statistically significant differences in the $\mathrm{C}$ concentrations between the organic and the mineral horizons $\left(182.0 \pm 58.5 \mathrm{mg} \mathrm{g}^{-1}\right.$; mean difference $\pm 95 \%$ confidence interval half-width; $p$ value $<0.001$; analysis of variance $F$ test with plot and horizon as factors), and a small but significant difference among the two plots $\left(74.2 \pm 58.5 \mathrm{mg} \mathrm{g}^{-1}\right.$, $p$ value $=0.017)$. $\mathrm{N}$ content showed differences between horizons as well, but no differences between the plots (Fig. 2a, b). 

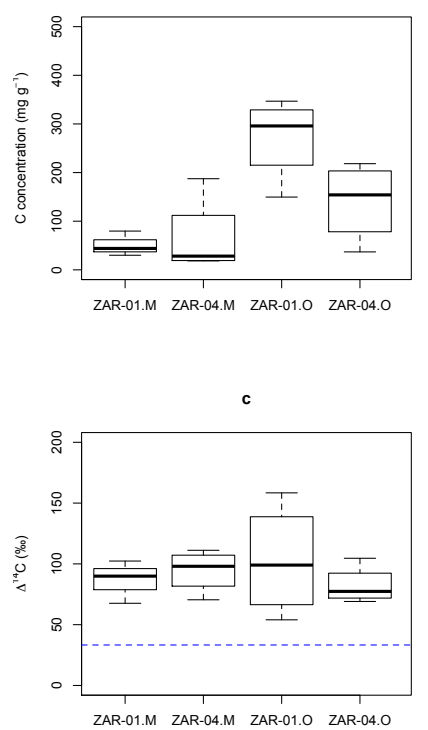
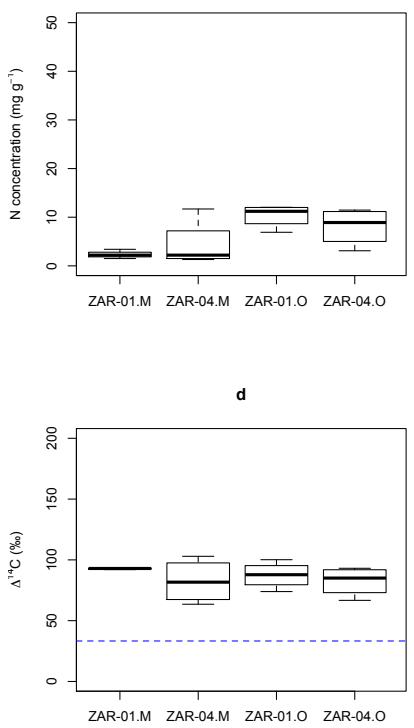

Fig. 2. Topsoil concentrations of (a) carbon, (b) nitrogen, and radiocarbon in the (c) bulk soil and (d) the respired $\mathrm{CO}_{2}$ after incubations for the organic layer $(\mathrm{O})$ and the mineral horizon $(\mathrm{M})$. The broken line in the bottom panels represents the $\Delta^{14} \mathrm{C}$ value of the atmosphere for the year of sampling.

The post hoc Tukey HSD test showed that the differences between the two plots were due to the differences across horizons and not due to differences between the same horizons. The difference between the mean $\mathrm{C}$ content of the mineral horizon for the two plots was $23.3 \pm 118.1 \mathrm{mg} \mathrm{g}^{-1}$ and showed no statistical differences (adjusted $p$ value $=0.931$ ). For the organic horizon, the difference between the two plots was $93.6 \pm 109.2$ and was not statistically significant (adjusted $p$ value $=0.102$ )

The radiocarbon signature of the bulk soil and the respired $\mathrm{CO}_{2}$ from the incubations showed no significant differences between plots or horizons ( $p$ value $>0.1$ in all cases; analysis of variance $F$ test). The mean $\Delta^{14} \mathrm{C}$ in bulk soil measured across plots and horizons was $91.76 \pm 26.12 \%$ (mean \pm standard deviation), while the mean $\Delta{ }^{14} \mathrm{C}$ in respired $\mathrm{CO}_{2}$ was $85.5 \pm 12.06 \%$ o. The positive values of $\Delta^{14} \mathrm{C}$ in both cases indicate that the carbon in the topsoil is mostly post-bomb (i.e., incorporated in the forest biomass after 1950) but without significant differences among the two forests ( $p$ value $>0.1$ in all cases, Fig. 2c, d).

These results are consistent with hypothesis 1: similar amounts of carbon inputs to both soils result in similar amounts of carbon contents in the litter layer and the first $5 \mathrm{~cm}$ of the mineral soil. In addition, $\Delta{ }^{14} \mathrm{C}$ values in the bulk soil and heterotrophic respiration showed that rates of carbon cycling are similar in the topsoil of both systems.

\subsection{Subsoil}

In the high-stature forest (ZAR-04), organic carbon decreased with depth exponentially as expected for welldrained profiles (Jobbágy and Jackson, 2000; Quesada et al., 2011). In contrast, organic carbon was higher deeper in the profile for the low-stature forest (ZAR-01) because of the presence of the Bh horizon in this Podzol, which stores more carbon than the upper A horizon. The E horizon of the Podzol, at $50 \mathrm{~cm}$ depth, contained negligible amounts of $\mathrm{C}$, and therefore no $\mathrm{CO}_{2}$ was collected during the incubations for this horizon (Table 3).

The amount of carbon respired during the incubation period also decreased exponentially with depth in the Alisol soil following the same trend as the carbon content (Table 3). In the Podzol soil, the amount of carbon respired during the incubation was lower in the upper A horizon than in the $\mathrm{Bh}$ horizon, also an indication that the amount of respiration was proportional to the amount of carbon content at each horizon. In the A horizon, the amount of $\mathrm{C}$ respired in the Podzol was much lower than what was respired in the Alisol; while in the Bh horizon of the Podzol, at $70 \mathrm{~cm}$ depth, the respired C was higher than what it was respired in the B horizon of the Alisol at $55 \mathrm{~cm}$ depth.

The $\Delta^{14} \mathrm{C}$ values of soil carbon also decreased with depth in both soils (Fig. 3), indicating that the age of carbon increases with depth. Only in the first $5-10 \mathrm{~cm}$, it was possible to observe dominant proportions of recent carbon fixed after 1950. Interestingly, the $\Delta^{14} \mathrm{C}$ values between the Alisol and the Podzol were relatively similar at the deepest sampled points.

The ${ }^{14} \mathrm{C}$ values of the respired $\mathrm{CO}_{2}$ for the different depths in the Alisol were all positive (Fig. 3), indicating that the more readily decomposed $\mathrm{C}$ in these soils was recently fixed (after 1950) while a larger proportion of old carbon was not preferentially decomposed by microorganisms, and it is perhaps bounded to mineral surfaces. In contrast, the $\Delta^{14} \mathrm{C}$ values of the respired $\mathrm{C}$ in the Podzol were negative in the $\mathrm{Bh}$ horizon and far from the values expected in the case that carbon fixed after $1950 \mathrm{AD}$ had been incorporated in this horizon. Therefore, the readily available $\mathrm{C}$ for decomposition in the $\mathrm{Bh}$ horizon is much older than $\mathrm{C}$ fixed after $1950 \mathrm{AD}$.

\subsection{Model results}

Fitting the obtained radiocarbon data to the model described by Eq. (2) showed that there are important differences between the two forests in terms of the amount of carbon transferred from the topsoil to the subsoil (Table 4, Fig. 4). While in the high-stature terra firme forest $30 \%$ of the carbon that decomposes from the fast pool in the topsoil is transferred to the subsoil $\left(\alpha_{3,1}=0.3\right)$, in the Podzol soil this proportional amount of $\mathrm{C}$ transfer is only $1.7 \%\left(\alpha_{3,1}=0.017\right)$. The transfer of $\mathrm{C}$ in the slow pool from the topsoil to the subsoil is 
Table 3. Carbon content and heterotrophic respiration from samples collected in two profiles at different depths in the Alisol (ZAR-04) and the Podzol (ZAR-01).

\begin{tabular}{lrrr}
\hline $\begin{array}{l}\text { Soil type } \\
\text { (plot) }\end{array}$ & $\begin{array}{r}\text { Depth } \\
(\mathrm{cm})\end{array}$ & $\begin{array}{r}\mathrm{C} \text { content } \\
\left(\mathrm{mg} \mathrm{g}^{-1}\right)\end{array}$ & $\begin{array}{r}\mathrm{Rh} \\
\left(\mu \mathrm{mg}^{-1}\right. \\
\left.\mathrm{day}^{-1}\right)\end{array}$ \\
\hline Alisol (ZAR-04) & 5 & 23.5 & 0.48 \\
& 15 & 6.3 & 0.24 \\
& 55 & 4.5 & 0.23 \\
Podzol (ZAR-01) & 10 & 12.0 & 0.09 \\
& 50 & 0.1 & - \\
& 70 & 16.1 & 0.08 \\
\hline
\end{tabular}

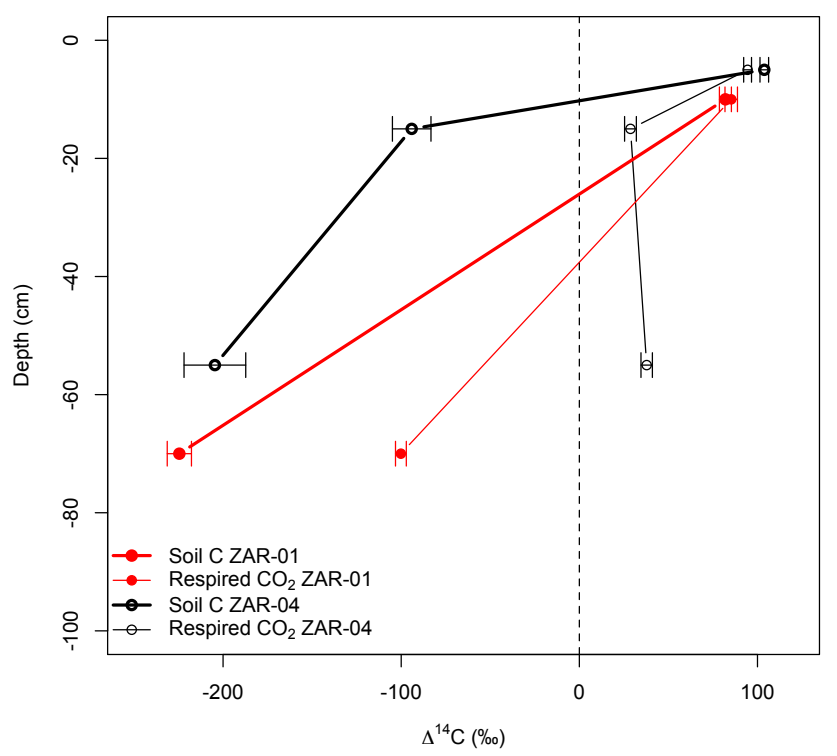

Fig. 3. Depth profile of the $\Delta^{14} \mathrm{C}$ in bulk soil and respired $\mathrm{CO}_{2}$ for the low-stature forest on a Podzol soil (ZAR-01), and the highstature forest on a well-drained Alisol soil (ZAR-04).

even lower for the two forests: $0.01 \%$ in the terra firme forest and $0.25 \%$ in the Podzol soil (Table 4).

In the Alisol, a significant proportion of radiocarbon inputs to the subsoil are provided by root inputs, while in the Podzol this source of $\mathrm{C}$ inputs is missing due to anoxic conditions below the A horizon.

\section{Discussion}

The carbon content, as well as the radiocarbon values obtained here, indicates important differences in the overall carbon dynamics between the two soils. In agreement with our first hypothesis, we did not find differences between the two forests in terms of the carbon concentrations and the rates of carbon cycling in the topsoil. However, contrary to our second hypothesis, we found important differences in the rates
Table 4. Model parameters for the Podzol and the Alisol soils obtained from the radiocarbon measurements. Values of $k_{i}$ are in units of $\mathrm{yr}^{-1}$, and all other parameters are unitless.

\begin{tabular}{lcc}
\hline Parameter & Podzol soil & Alisol soil \\
\hline$k_{1}$ & 2.0000 & 2.0000 \\
$k_{2}$ & 0.1100 & 0.9500 \\
$k_{3}$ & 1.0000 & 1.0000 \\
$k_{4}$ & 0.0002 & 0.0002 \\
$\alpha_{31}$ & 0.0170 & 0.3000 \\
$\alpha_{42}$ & 0.0025 & 0.0001 \\
$\gamma_{1}$ & 0.1000 & 0.1000 \\
$\gamma_{2}$ & 0.1000 & 0.9800 \\
\hline
\end{tabular}
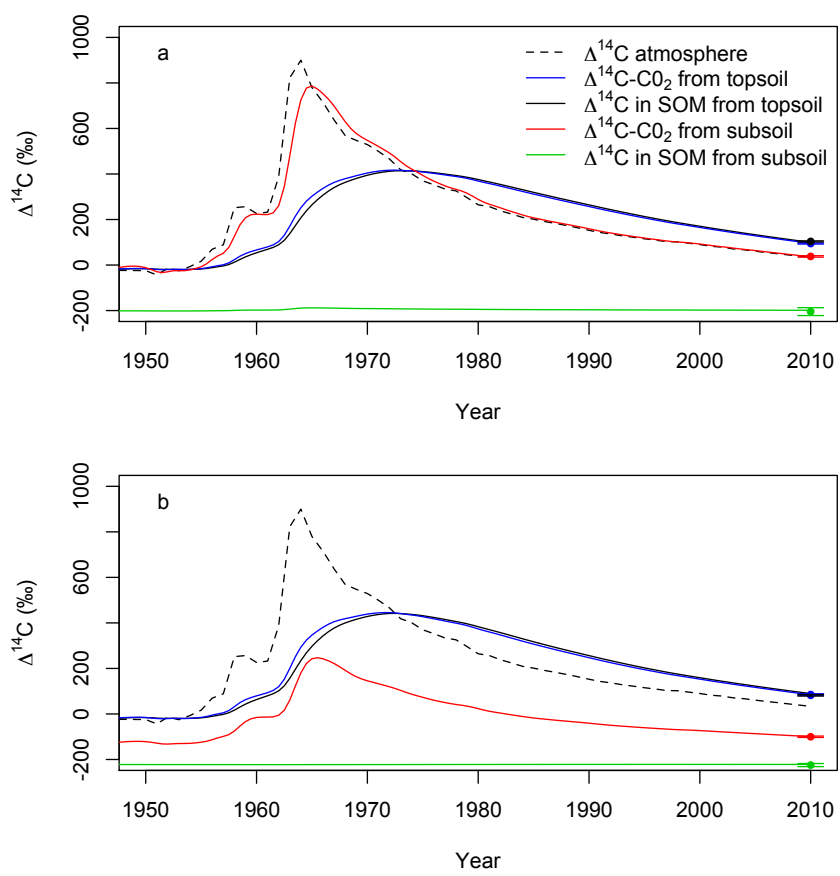

Fig. 4. Model predictions of the temporal behavior of radiocarbon during the bomb period (after 1950) for the (a) high-stature forest on an Alisol soil (ZAR-04) and (b) the low-stature forest on a Podzol soil (ZAR-01). The points indicate measured $\Delta^{14} \mathrm{C}$ values \pm their analytical uncertainty.

of vertical C transfer between the two soils. We will discuss these differences between topsoil and subsoil $\mathrm{C}$ dynamics in the next sections.

\subsection{Topsoil carbon dynamics}

Despite important differences in aboveground NPP between the two forests, we did not observe differences in carbon and radiocarbon concentrations in the litter layer and the topsoil at both sites. The low-stature forest had $50 \%$ more fine-root production than the high-stature forest, which results in relatively similar amounts of carbon inputs to the topsoil in both forests (Table 1). Total carbon inputs to the topsoil are 
key determinants of the total carbon storage in tropical soils (Trumbore et al., 1995), and our results confirm this idea.

With similar amounts of $\mathrm{C}$ inputs and concentrations in the topsoil, it seems plausible that decomposition rates of litter and soil organic matter in the first $5 \mathrm{~cm}$ of both soils are similar on an annual basis, despite important differences in soil hydrology. High water-table levels are commonly associated with important decreases in decomposition rates (Skopp et al., 2009; Jungkunst and Fiedler, 2007), and it is likely that decomposition rates are reduced during the wet season when the A horizon of the Podzol soil is under water stagnation. However, in order to maintain similar carbon concentrations in the first $5 \mathrm{~cm}$ as in the well-drained Alisol, either decomposition rates increase significantly in the Podzol when the water table is low or there are significant transfers of carbon vertically or horizontally. Our results rule out the possibility of significant rates of vertical $\mathrm{C}$ transfers. Therefore, the only two possibilities to explain similar $\mathrm{C}$ contents in the litter layer and the first $5 \mathrm{~cm}$ of the mineral soil are higher decomposition rates during the low water-table conditions or significant lateral $\mathrm{C}$ transfers.

\subsection{Subsoil carbon dynamics}

Our radiocarbon data and the modeling results provide strong evidence against the hypothesis of significant vertical $\mathrm{C}$ transfers in the Podzol soil. $\Delta^{14} \mathrm{C}$ values in the bulk soil and the respired $\mathrm{C}$ from the incubated samples of the Ortsteinic horizon did not provide indications of incorporation of bomb radiocarbon. Furthermore, the more readily available carbon for decomposition and trapped as $\mathrm{CO}_{2}$ gas in the incubations was mostly of pre-bomb origin, contrary to what was found for the Alisol.

Our results are at odds with estimates presented by Montes et al. (2011) about the magnitude of DOC transfers in podzols in Brazil in the vicinity of São Gabriel da Cachoeira city. These authors estimated an annual vertical transfer to the $\mathrm{Bh}$ horizon equivalent to $16.8 \mathrm{~g} \mathrm{C} \mathrm{m}^{-2} \mathrm{yr}^{-1}$, while our simulations predict only $2.1 \mathrm{~g} \mathrm{C} \mathrm{m}^{-2} \mathrm{yr}^{-1}$ of vertical transfers for the Podzol we studied, which is a factor of 8 less from this previous prediction. In contrast, our model predicts vertical transfer in the Alisol as $13.2 \mathrm{~g} \mathrm{C} \mathrm{m}^{-2} \mathrm{yr}^{-1}$, six times more than what was predicted for the Podzol.

Our data also challenge the assumption that this whitesand soil is actually a true Podzol. By definition, Podzols are characterized by eluviation of metals and organic materials, but this eluviation processes had either stopped at a certain point in time or never occurred at our site. Other authors had previously questioned the classification of white-sand soils as Podzols in Amazon forests (Klinge, 1965; Bravard and Righi, 1989; do Nascimento et al., 2004). For instance, Klinge (1965) suggested that the deep organic horizon may not be necessarily of eluvial origin, but instead a buried A horizon. Another possibility, suggested by do Nascimento et al. (2004) in their model of podzolization for the Amazon, is that this soil is in a very late stage of development, and true podzolization has already stopped. It is also likely that the genesis of the soil we studied differs considerably from previously studied Podzols in the central Amazon Basin.

Taking together the results from our radiocarbon analyses from the topsoil and subsoil, it is likely that lateral $\mathrm{C}$ transfers play a mayor role in the Podzol we studied. Rates of $\mathrm{C}$ cycling in the topsoil appear to be similar between the Alisol and the Podzol. In the subsoil, however, a considerable amount of $\mathrm{C}$ seems to be transported vertically in the Alisol where it is adsorbed to the clay minerals. Contrarily, vertical $\mathrm{C}$ transfers and illuviation in the $\mathrm{Bh}$ horizon seem to be negligible in the profile we studied. This may imply that most of the organic matter decomposed from the topsoil and dissolved is transported laterally. This is consistent with ideas related to the origin of organic compounds in black water rivers in the Amazon, which contain significant amount of organic carbon draining from the groundwater of podzolic soils (Janzen, 1974; Leenheer, 1980; Chauvel et al., 1987).

To our knowledge, only one study had previously measured the radiocarbon content in the illuvial horizon of a Podzol in the Amazon Basin. Horbe et al. (2004) measured the isotopic composition of the organic matter in a Podzol north of Manaus. They found conventional radiocarbon ages between 1960 and $2810 \mathrm{yr}$ BP and suggested that the organic matter in the $\mathrm{Bh}$ horizon was of relatively recent origin. These radiocarbon ages, however, are difficult to interpret for two reasons: (1) there are important deviations between the true age of a sample and the radiocarbon age given the temporal variability of the atmospheric radiocarbon record (Reimer et al., 2009). (2) Additions and losses of carbon over time are better tracked with a model that incorporates the atmospheric radiocarbon record, the rates of organic matter decomposition, and radioactive decay, all processes occurring simultaneously (Trumbore, 1993, 2009). Our modeling approach incorporated all these processes and more confidently can attribute the observed $\Delta^{14} \mathrm{C}$ values to differences in the rates of organic matter decomposition and transfers along the profile.

\section{Conclusions}

Measurements of organic carbon and radiocarbon contents in two contrasting soils of western Amazonia showed similar rates of carbon cycling in the litter layer and the first $5 \mathrm{~cm}$ despite large differences in aboveground NPP between the two sites. A low-stature forest growing under a Podzol soil showed large values of fine-root production and therefore similar rates of total carbon inputs to the soil compared to a high-stature terra firme forest growing under a well-drained Alisol. Both soils presented no differences in their carbon content and $\Delta^{14} \mathrm{C}$ values measured in the litter layer and the topsoil (first $5 \mathrm{~cm}$ ). 
Important differences between the two forests were found in the subsoil. While in the Alisol carbon contents decreased exponentially, the Ortsteinic Bh horizon presented large C contents at $65 \mathrm{~cm}$ depth in the Podzol, with larger $\mathrm{C}$ contents than in the A horizon of the same soil. However, our radiocarbon measurements do not provide evidence for this organic horizon formed as a result of significant vertical $\mathrm{C}$ transfers. In contrast with the Alisol, $\Delta{ }^{14} \mathrm{C}$ values measured in this horizon did not incorporate radiocarbon signatures from the atmospheric radiocarbon bomb period. With the aid of a simulation model, we predict 8 times less vertical C transfers than what has been previously predicted for this type of soils, challenging our previous assumptions about the formation of the Bh horizon of this Podzol soil.

\section{Supplementary material related to this article is available online at: http://www.biogeosciences.net/10/ 3455/2013/bg-10-3455-2013-supplement.zip.}

Acknowledgements. Financial support was provided by the Max Planck Society. S. E. Trumbore provided important guidance and support for this project. U.-N. Meyer provided significant help with laboratory incubations, and I. Schöning provided comments on a previous version of the manuscript. We would also like to thank I. Kuhlmann, A. Steinhof, X. Xu, and I. Hilke for laboratory support and chemical analyses, M. A. Arcangel for fieldwork assistance and other personnel from the Zafire Biological Station and the Research Group on Ecology of Tropical Terrestrial Ecosystems of the National University of Colombia at Leticia.

The service charges for this open access publication have been covered by the Max Planck Society.

Edited by: E. Veldkamp

\section{References}

Aragão, L. E. O. C., Malhi, Y., Metcalfe, D. B., Silva-Espejo, J. E., Jiménez, E., Navarrete, D., Almeida, S., Costa, A. C. L., Salinas, N., Phillips, O. L., Anderson, L. O., Alvarez, E., Baker, T. R., Goncalvez, P. H., Huamán-Ovalle, J., Mamani-Solórzano, M., Meir, P., Monteagudo, A., Patiño, S., Peñuela, M. C., Prieto, A., Quesada, C. A., Rozas-Dávila, A., Rudas, A., Silva Jr., J. A., and Vásquez, R.: Above- and below-ground net primary productivity across ten Amazonian forests on contrasting soils, Biogeosciences, 6, 2759-2778, doi:10.5194/bg-6-2759-2009, 2009.

Baisden, W. and Parfitt, R.: Bomb ${ }^{14} \mathrm{C}$ enrichment indicates decadal C pool in deep soil?, Biogeochemistry, 85, 59-68, 2007.

Bravard, S. and Righi, D.: Geochemical differences in an oxisolspodosol toposequence of Amazonia, Brazil, Geoderma, 44, 2942, doi:10.1016/0016-7061(89)90004-9, 1989.

Buurman, P. and Jongmans, A.: Podzolisation and soil organic matter dynamics, Geoderma, 125, 71-83, 2005.
Chapin, F. S., Woodwell, G. M., Randerson, J. T., Rastetter, E. B., Lovett, G. M., Baldocchi, D. D., Clark, D. A., Harmon, M. E., Schimel, D. S., Valentini, R., Wirth, C., Aber, J. D., Cole, J. J., Goulden, M. L., Harden, J. W., Heimann, M., Howarth, R. W., Matson, P. A., McGuire, A. D., Melillo, J. M., Mooney, H. A., Neff, J. C., Houghton, R. A., Pace, M. L., Ryan, M. G., Running, S. W., Sala, O. E., Schlesinger, W. H., and Schulze, E. D.: Reconciling carbon-cycle concepts, terminology, and methods, Ecosystems, 9, 1041-1050, doi:10.1007/s10021-005-01057, 2006.

Chauvel, A., Lucas, Y., and Boulet, R.: On the genesis of the soil mantle of the region of manaus, central Amazonia, Brazil, Experientia 43, 234-241, 1987.

Cleveland, C. C., Townsend, A. R., Taylor, P., Alvarez-Clare, S., Bustamante, M. M. C., Chuyong, G., Dobrowski, S. Z., Grierson, P., Harms, K. E., Houlton, B. Z., Marklein, A., Parton, W., Porder, S., Reed, S. C., Sierra, C. A., Silver, W. L., Tanner, E. V. J., and Wieder, W. R.: Relationships among net primary productivity, nutrients and climate in tropical rain forest: a pantropical analysis, Ecol. Lett., 14, 939-947, 2011.

do Nascimento, N., Bueno, G., Fritsch, E., Herbillon, A., Allard, T., Melfi, A., Astolfo, R., Boucher, H., and Li, Y.: Podzolization as a deferralitization process: a study of an Acrisol-Podzol sequence derived from Palaeozoic sandstones in the northern upper Amazon Basin, Eur. J. Soil Sci., 55, 523-538, doi:10.1111/j.13652389.2004.00616.x, 2004.

Duivenvoorden, J. and Lips, J.: A land-ecological study of soils, vegetation, and plant diversity in Colombian Amazonia, Trobenbos Series 12, Tropenbos Foundation, 1995.

Gaudinski, J., Trumbore, S., Davidson, E., and Zheng, S.: Soil carbon cycling in a temperate forest: radiocarbon-based estimates of residence times, sequestration rates and partitioning fluxes, Biogeochemistry, 51, 33-69, 2000.

Horbe, A. M. C., Horbe, M. A., and Suguio, K.: Tropical Spodosols in northeastern Amazonas state, Brazil, Geoderma, 119, 55-68, doi:10.1016/S0016-7061(03)00233-7, 2004.

Jackson, R., Canadell, J., Ehleringer, J., Mooney, H., Sala, O., and Schulze, E.: A global analysis of root distributions for terrestrial biomes, Oecologia, 108, 389-411, 1996.

Janzen, D. H.: Tropical blackwater rivers, animals, and mast fruiting by the dipterocarpaceae, Biotropica, 6, 69-103, 1974.

Jiménez, E. M., Moreno, F. H., Peñuela, M. C., Patiño, S., and Lloyd, J.: Fine root dynamics for forests on contrasting soils in the Colombian Amazon, Biogeosciences, 6, 2809-2827, doi:10.5194/bg-6-2809-2009, 2009.

Jiménez, E. M., Peñuela, M. C., Sierra, C. A., Patiño, S., Lloyd, J., Phillips, O., Navarrete, D., Prieto, A., Rudas, A., Álvarez, E., Quesada, C. A., and Grande, M. A.: Carbon allocation depends on soils and varies over time in two tropical forests, in preparation, 2013.

Jobbágy, E. and Jackson, R.: The vertical distribution of soil organic carbon and its relation to climate and vegetation, Ecol. Appl., 10, 423-436, 2000.

Jungkunst, H. F. and Fiedler, S.: Latitudinal differentiated water table control of carbon dioxide, methane and nitrous oxide fluxes from hydromorphic soils: feedbacks to climate change, Glob. Change Biol., 13, 2668-2683, doi:10.1111/j.13652486.2007.01459.x, 2007. 
Klinge, H.: Podzol soils in the Amazon basin, J. Soil Sci., 16, 95103, doi:10.1111/j.1365-2389.1965.tb01423.x, 1965.

Leenheer, J. A.: Origin and nature of humic substance in the waters of the amazon river basin. Acta Amazonica, 10, 513-526, 1980.

Levin, I. and Kromer, B.: The tropospheric ${ }^{14} \mathrm{CO}_{2}$ level in midlatitudes of the Northern Hemisphere (1959-2003), Radiocarbon, 46, 1261-1272, 2004.

Lucas, Y., Montes, C. R., Mounier, S., Loustau Cazalet, M., Ishida, D., Achard, R., Garnier, C., Coulomb, B., and Melfi, A. J.: Biogeochemistry of an Amazonian podzol-ferralsol soil system with white kaolin, Biogeosciences, 9, 3705-3720, doi:10.5194/bg-9-3705-2012, 2012.

Malhi, Y., Doughty, C., and Galbraith, D.: The allocation of ecosystem net primary productivity in tropical forests, Philos. T. Roy. Soc. B, 366, 3225-3245, 2011.

Montes, C. R., Lucas, Y., Pereira, O. J. R., Achard, R., Grimaldi, M., and Melfi, A. J.: Deep plant-derived carbon storage in Amazonian podzols, Biogeosciences, 8, 113-120, doi:10.5194/bg-8113-2011, 2011.

Quesada, C. A., Lloyd, J., Schwarz, M., Patiño, S., Baker, T. R., Czimczik, C., Fyllas, N. M., Martinelli, L., Nardoto, G. B., Schmerler, J., Santos, A. J. B., Hodnett, M. G., Herrera, R., Luizão, F. J., Arneth, A., Lloyd, G., Dezzeo, N., Hilke, I., Kuhlmann, I., Raessler, M., Brand, W. A., Geilmann, H., Moraes Filho, J. O., Carvalho, F. P., Araujo Filho, R. N., Chaves, J. E., Cruz Junior, O. F., Pimentel, T. P., and Paiva, R.: Variations in chemical and physical properties of Amazon forest soils in relation to their genesis, Biogeosciences, 7, 1515-1541, doi:10.5194/bg-7-15152010, 2010.

Quesada, C. A., Lloyd, J., Anderson, L. O., Fyllas, N. M., Schwarz, M., and Czimczik, C. I.: Soils of Amazonia with particular reference to the RAINFOR sites, Biogeosciences, 8, 14151440, doi:10.5194/bg-8-1415-2011, 2011.

Quesada, C. A., Phillips, O. L., Schwarz, M., Czimczik, C. I., Baker, T. R., Patiño, S., Fyllas, N. M., Hodnett, M. G., Herrera, R., Almeida, S., Alvarez Dávila, E., Arneth, A., Arroyo, L., Chao, K. J., Dezzeo, N., Erwin, T., di Fiore, A., Higuchi, N., Honorio Coronado, E., Jimenez, E. M., Killeen, T., Lezama, A. T., Lloyd, G., López-González, G., Luizão, F. J., Malhi, Y., Monteagudo, A., Neill, D. A., Núñez Vargas, P., Paiva, R., Peacock, J., Peñuela, M. C., Peña Cruz, A., Pitman, N., Priante Filho, N., Prieto, A., Ramírez, H., Rudas, A., Salomão, R., Santos, A. J. B., Schmerler, J., Silva, N., Silveira, M., Vásquez, R., Vieira, I., Terborgh, J., and Lloyd, J.: Basin-wide variations in Amazon forest structure and function are mediated by both soils and climate, Biogeosciences, 9, 2203-2246, doi:10.5194/bg-9-2203-2012, 2012.
Reimer, P., Baillie, M., Bard, E., Bayliss, A., Beck, J., Blackwell, P., Ramsey, C., Buck, C., Burr, G., Edwards, R., Friedrich, M., Grootes, P.M., Guilderson, T. P., Hajdas, I., Heaton, T. J., Hogg, A. G., Hughen, K.A., Kaiser, K. F., Kromer, B., McCormac, F. G., Manning, S. W., Reimer, R. W., Richards, D. A., Southon, J. R., Talamo, S., Turney, C. S. M., van der Plicht, J., and Weyhenmeyer, C. E.: IntCa109 and Marine09 radiocarbon age calibration curves, 0-50 000 yr cal BP, Radiocarbon, 51, 1111-1150, 2009.

Sierra, C. A., Müller, M., and Trumbore, S. E.: Models of soil organic matter decomposition: the SoilR package, version 1.0, Geosci. Model Dev., 5, 1045-1060, doi:10.5194/gmd-5-10452012, 2012a

Sierra, C. A., Trumbore, S. E., Davidson, E. A., Frey, S. D., Savage, K. E., and Hopkins, F. M.: Predicting decadal trends and transient responses of radiocarbon storage and fluxes in a temperate forest soil, Biogeosciences, 9, 3013-3028, doi:10.5194/bg-93013-2012, 2012b.

Skopp, J. Jawson, M. D., and Doran, J. W.: Steady-state aerobic microbial activity as a function of soil water content, Soil Sci. Soc. Am. J., 54, 1619-1625, 1990.

Stuiver, M. and Polach, H. A.: Rerporting of ${ }^{14} \mathrm{C}$ data, Radiocarbon, 19, 355-363, 1977.

Townsend, A. R., Asner, G. P., and Cleveland, C. C.: The biogeochemical heterogeneity of tropical forests, Trends Ecol. Evol., 23, 424-431, 2008.

Trumbore, S.: Radiocarbon and soil carbon dynamics, Ann. Rev. Earth Planet. Sci., 37, 47-66, 2009.

Trumbore, S. E.: Comparison of carbon dynamics in tropical and temperate soils using radiocarbon measurements, Global Biogeochem. Cy., 7, 275-290, 1993.

Trumbore, S. E., Davidson, E. A., Barbosa de Camargo, P., Nepstad, D. C., and Martinelli, L. A.: Belowground cycling of carbon in forests and pastures of eastern Amazonia, Global Biogeochem. Cy., 9, 515-528, 1995.

Wieder, W. R., Cleveland, C. C., and Townsend, A. R.: Controls over leaf litter decomposition in wet tropical forests, Ecology, 90, 3333-3341, 2009.

Yang, X. and Post, W. M.: Phosphorus transformations as a function of pedogenesis: A synthesis of soil phosphorus data using Hedley fractionation method, Biogeosciences, 8, 2907-2916, doi:10.5194/bg-8-2907-2011, 2011. 